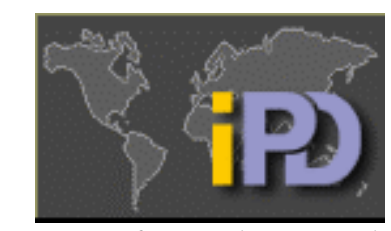

Initiative for Policy Dialogue

Working Papers

\title{
Capital Market Liberalization and Poverty
}

\author{
Preliminary Draft for IPD Capital Market Task force
}

Andrew Charlton and Joseph E. Stiglitz ${ }^{1}$

June 2004

\section{Introduction}

International financial liberalization opens national economies to cross-border capital flows which present both risks and opportunities for different sectors of the economy. From the point of view of poverty, liberalization increases the exposure of the national economy to international volatility and, at the same time, presents domestic agents with some compensating opportunities to diversify those risks. In this paper we review analytical studies and cross-country empirical evidence on the effects of financial liberalization on the lives of the poor.

In developing countries, the poverty effects of macroeconomic reforms are determined by the impact of those policies on income growth and the extent to which any new prosperity is distributed progressively to the lowest income groups. A number of studies have investigated the effects of capital market liberalization on the growth of average incomes. In general, this literature establishes a compelling case for caution: capital market liberalization is not robustly associated with economic growth in developing countries, but it does appear to exacerbate macroeconomic volatility and increase the incidence of financial crises (Rodrik 1998, Singh 2002, Prasad et al 2003). To the extent that liberalization offers compensatory advantages,

\footnotetext{
${ }^{1}$ The authors would like to thank Andrew Glyn.
} 
these lie in improved access to advanced credit markets and new opportunities to diversify risk and insure against volatility.

However not all sectors of the economy are equally equipped to take advantage of these benefits, and not all sectors are equally affected by increased volatility. In general empirical evidence suggests that new opportunities accrue disproportionately to the rich, while the adverse effects of volatility impact disproportionately on the poor. For these reasons it is not surprising that cross-country empirical studies link capital market liberalization with deterioration in various measures of inequality (Quinn 1997, Das and Mohapatra 2003, Calderon and Chong 2001, Harrison 2002, Jayadev 2004).

This paper proceeds by first reviewing the neoclassical theoretical framework from which orthodox capital market liberalization policies have been derived. This paradigm ignores the idiosyncrasies of financial markets which distinguish capital market liberalization from other reforms that have been shown to be generally propoor, such as (carefully implemented) trade liberalization. The weaknesses of the orthodox paradigm are reflected in cross-country empirical studies which, contrary to neoclassical predictions, generally establish a negative relationship between the extent of capital market liberalization and various measures of inequality.

We explain this relationship by considering five channels through which liberalization may affect the distribution of income and poverty levels in developing countries. In each channel, we find that the overwhelming share of risks fall on the poor: i) the poor are the most vulnerable to macroeconomic volatility because they have the least ability to cope with risk and the weakest access to insurance markets; ii) the poor are the hardest hit by the dire effects of financial crises: their welfare losses are severe and persist long after the crisis abates; iii) increasing mobility of capital weakens the bargaining position of poor labourers and may lead to a reduction in their share of total output; iv) international financial integration may reduce governments' autonomy over fiscal policy and can restrict the scope for progressive transfers, social protection, and anti-poverty programs; and v) financial liberalization increases competition from foreign banks, potentially increasing financial efficiency but also reducing credit availability to rural and poor sections of the economy.

We should be clear that this paper focuses on the effects of liberalization polices which facilitate short-term capital flows. Other types of capital flows, such as foreign direct investment, may have different effects on economic growth and poverty. ${ }^{2}$

\section{Conceptual Issues}

The case for capital market liberalization is mainly based on standard efficiency arguments. In theory, the level of international financial liberalization is the degree to which lenders and borrowers can conduct cross-border transactions without incurring government imposed costs, delays, or uncertainty. In the simplest neoclassical

\footnotetext{
${ }^{2}$ There is fairly strong evidence of the positive effects of FDI on economic growth. See Borensztein, De Gregorio, and Lee (1998) and De Mello (1999).
} 
frameworks, capital market liberalization removes these distortions and generates an efficiency dividend when capital is redeployed from low to higher marginal productivity uses. ${ }^{3}$ Summers (2000) summarizes the orthodox perspective: "the abstract argument for a competitive financial system parallels the argument for competitive markets in general ... Just as trade in goods across jurisdictions has benefits, so too will intertemporal trade and trade that shares risks across jurisdictions have benefits." As efficiency increases, incomes rise and, ceteris paribus, we expect poverty to fall. ${ }^{4}$

However this neoclassical paradigm rests on a large number of assumptions which are of questionable validity in any country, and are particularly problematic in developing countries. Rakshit (2001) argues that the benefits of open capital markets predicted in neoclassical theory rest on three key assumptions; i) capital and labor resources are fully employed everywhere; ii) capital flows themselves do not adversely affect macroeconomic stability; and iii) international capital movements are determined by long-term returns on investment in different countries. Few of these assumptions are likely to hold in developing countries.

Restrictions on capital flows are certainly distortionary, but this may be optimal in the presence of other distortions (Brecher and Bhagwati, 1982), as predicted in the theory of the second best. Such distortions are pervasive in developing countries where industry policies are often implemented to protect and promote domestic industries; where economic institutions are often weak and only weakly able to enforce competition law and property rights; and where informational asymmetries abound. In addition, poor people in developing countries face generally weak social safety nets, poor risk markets, and high rates of unemployment and underemployment.

The models of perfectly functioning markets are even less relevant when one considers that liberalization often takes place in the context of contemporaneous economic shocks. For example liberalization has been promoted as a response to financial crises; during which governments are already dealing with difficulties servicing domestic debt and a host of other stabilization policies. In recognition of the peculiar circumstances of developing countries, the G-24 have repeatedly expressed caution in response to IMF demands for capital market liberalization, and have questioned the appropriateness of the liberalization programs prescribed by the IMF to deal with financial crises (Caracas Declaration, February 1997).

The neoclassical paradigm also assumes that financial and capital markets are essentially the same as other markets for goods and services. This ignores the critical role of information in financial and capital markets whose main function is to assess likely returns, ration credit, and monitor performance. Markets for information are fundamentally different to 'ordinary' markets, and where information is imperfect,

\footnotetext{
${ }^{3}$ In this sense capital market liberalization is similar to trade liberalization. Trade between time periods (international borrowing and lending) is analogous to trade between countries. See Frenkel and Razin (1996). Another (political economy) rational for liberalization is also often advanced which suggests that liberalization increases pressures of governments to pursue 'sound policies'. We discuss this in a later section.

${ }^{4}$ There is recent evidence that the poor receive a proportionate share in economic growth. Dollar and Kray (2001) find that income growth of the poor is one-for-one with the mean income growth of the population.
} 
they may not produce Pareto efficient outcomes (Greenwald and Stiglitz, 1986). Information problems create market failures which inhibit the efficient allocation of capital and provide a rationale for some types of government intervention in capital markets. Incomplete information may create adverse selection problems if highly profitable low-risk projects are unable to attract finance at rates reflecting their quality. Alternatively government guarantees to private banks and enterprises may lead to a misallocation of resources and create moral hazard problems (Mckinnon and Pill 1997). Such guarantees will lead firms to over-invest in high-risk projects.

Capital markets are particularly sensitive to information, partly because they exhibit herding patterns which exacerbate volatility. Herding occurs when fund managers choose to mimic each others actions because of the presence of private information which leads agents to make inferences based on the actions of others, or because of incentive structures which reward performance relative to average benchmarks. ${ }^{5}$ Several studies of capital markets in Korea have found evidence of herding among foreign investors before the crisis (Choe, Kho, and Stultz 1999, Kim and Wei 2002). Evidence of herding has also been found in regional and global studies (Kaminsky, Lyons, and Schmukler 2000, Borensztein and Gelos 2002). This kind of behaviour amplifies price movements and may lead to crises. As well as increasing a country's exposure to these phenomena, Calvo and Mendoza (1996) argue that international financial liberalization also encourages herding behaviour. In their model, international financial liberalization facilitates portfolio diversification and thereby reduces fund managers incentives to acquiring information about particular assets, consequently exacerbating information problems.

These features of financial markets cause instability; and by increasing the domestic economy's exposure to them, capital market liberalization may exacerbate economic fluctuations. Instability often has marked distributional consequences since, even in the rich countries like the United States, the poor bear a disproportionate burden in terms of increased unemployment (Furman and Stiglitz, 1998), and this effect is only stronger in poor countries where there are fewer automatic stabilizers. For these reasons the neoclassical link between capital market liberalization and economic growth does not hold in many scenarios.

\section{The empirical relationship between capital market liberalization, inequality, and poverty}

While there is no conclusive evidence demonstrating that CML will benefit the poor through increased economic growth, there is evidence that CML worsens the income distribution and increases poverty.

Early research suggested that capital account openness is related to inequitable distributional consequences. For a sample of 66 countries over the period 1960-1989, Quinn (1997) reports a positive correlation between the change in his capital account

\footnotetext{
${ }^{5}$ For a theoretical model see Krugman (1996). For a discussion of herding as a rational response to information problems see Devenow and Welch (1996).
} 
openness indicator ${ }^{6}$ and the GINI index. Quinn's results are statistically significant and robust across various specifications including controls for government expenditures and controls for international convergence of the GINI index over time. This relationship has been subsequently supported by further research. Das and Mohapatra (2003) analyse whether capital market reforms are associated with changes in inequality for 11 developing countries that undertook extensive economic reforms between 1986 and 1995. Rather than focussing on the GINI index, they attempt to investigate the dynamics of the income distribution, by observing the trend in the share of income owned by the $j^{\text {th }}$ quintile. Importantly, they control for global shocks and contemporaneously introduced stabilisation policies. ${ }^{7}$ Their results show that inequality increased following financial reform in almost all countries. The mean share of income held by the top quintile increased on average by 1.3 per cent. They also found that the income share of the middle class is strongly negatively correlated with liberalization, and there is a mixed reaction for the lowest income group, whose income share rose in some countries and fell in others but generally fell relative to their control group of 8 countries which did not experience liberalization. These results are consistent with Bekaert and Harvey (2000).

Calderon and Chong (2001) estimate a dynamic panel model to analyse the effects of various measures of international interdependence on income inequality using data for 97 countries over the period 1960-1995. They find contrasting results for the effects of trade and financial openness. Whereas an increase in trade volumes reduces inequality, measured by the GINI index, they find a negative and significant relationship between the intensity of balance of payments controls, as expressed by distortions in the foreign exchange market, and income inequality.

Considerable research has documented a relationship between financial openness and the size of the labor share of output (Harrison, 2002, Jayadev 2004). Diwan (2001) analyses 67 financial crises and finds that the labor share of output falls sharply during the crisis and only partially recovers. ${ }^{8}$

Instead of examining the effect of financial liberalization on the poverty rate or through income variables, several researchers have turned to poverty proxies derived from other aspects of the life of the poor, including life expectancy, infant mortality, and the status of women. Not only are these questions interesting in their own right, but they offer a number of advantages as an approach to poverty analysis. Arguably these variable provide a more direct link to welfare, and additionally their use avoids the multitude of problems associated with comparing income data across countries. ${ }^{9}$

Singh and Zammit (2000) examine the implications of capital flows for wages, employment, and the unpaid labor of women in developing countries. They argue that there are good reasons to believe that women are more disadvantaged by cyclical

\footnotetext{
${ }^{6}$ Quinn's (1997) measure of capital account liberalization is the change in a constructed index of openness over the period. The openness index is based on the intensity of capital restrictions in 7 areas. ${ }^{7}$ Henry (2000) shows that financial liberalization almost always occurs as part of broader macroeconomic regime change including reforms to exchange rate policies, trade liberalization, and privatization.

${ }^{8}$ We review the link between financial openness and the incidence of financial crises in a later section.

${ }^{9}$ Avoiding potentially important problems associated with variation in data across countries and, in the case of income measures, purchasing power parity adjustments which may not be reliable.
} 
instability and economic depressions than are men. In developed countries, downturns usually throw more men out of work, but the opposite is true in developing countries where the gender structure of employment is different (Howes and Singh 1995). In addition women suffer from the knock-on effects of downturns including the effect of any reduction in social expenditure on the well-being of their family, and the introduction of charges for previously free public services. As a consequence, the volume of unpaid work done by women may increase (Ozler 1999). There have been a number of studies of the effects of the Asian financial crisis on women. Nathan and Kelkar (1999) identified a drastic drop in women's incomes in the informal sector, for example, in Indonesia, income in weaving declined by more than 75 per cent during the crisis. Women also made up a majority of the migrant worker populations who were expelled from their host countries during the crisis.

Wei and $\mathrm{Wu}(2002)$ analyse the differential effects of financial and trade integration ${ }^{10}$ on improvements in health, as measured by life expectancy and infant mortality. In a sample of 79 countries over the period 1962-1997, they find that more trade openness is associated with longer life expectancy and lower infant mortality, after controlling for fixed effects, other macro and policy variables, and possible endogeneity of the openness variable. But they find that financial integration (measured as the ratio of total gross private inflows and outflows to GDP) is different. In their results, financial integration is associated with lower life expectancy and higher infant mortality, although both relationships are weak.

\section{Channels of Causation}

What explains this positive relationship between capital market liberalization and inequality and poverty? And why are the empirical results above so different to the predictions of the simplest theoretical models? From the classic Heckscher-Ohlin model we expect real openness to lead to an increase in the labor share of income in labor-abundant countries, and since the movement of commodities is a substitute for the movement of factors, we expect a similar result from financial openness. This implies that capital account openness should improve equity and reduce poverty. In section 2 we briefly described some features of developing countries that lead to pervasive market failures as well as some of the idiosyncratic features of financial markets. In this section we describe five channels through which capital market liberalization could affect income distribution and poverty in the context of these features.

\subsection{Volatility and Poverty}

Macroeconomic volatility is one channel through which financial liberalization increases both inequality and poverty. Theory suggests that international financial liberalization should facilitate international risk sharing (Obstfeld and Rogoff (1998)), and thereby increase the scope for consumption smoothing, a key determinant of

\footnotetext{
${ }^{10}$ Wei and Wu's (2002) study analyses trade integration rather than trade openness.
} 
economic welfare. However the evidence leads strongly towards the conclusion that financial liberalization increases the volatility of consumption. ${ }^{11}$ Kose, Prasad, and Terrones (2003) examine the macro volatility experienced by a large group of industrial and developing economies over the period 1960-99. They find that, on average, the volatility of consumption growth relative to that of income growth has increased for more financially integrated developing economies in the 1990s. Their results are robust using financial openness measures based on actual capital flows or indices measuring the extent of capital controls. They also report a threshold effect, where the adverse effects of increasing financial openness diminish for more developed countries. Prasad, Rogoff, Wei, and Kose (2003) report similar results from a comparison of the volatility experiences of a sample of 22 more financially integrated developing countries and 33 less financially integrated developing countries. They find that the most financially integrated have experienced the an increase in consumption volatility over the 1990s while the less financially integrated group of developing countries and the industrialised countries both experienced average declines in consumption volatility relative to the previous decade. Prasad et al conclude "financial integration has not provided better consumption smoothing opportunities for these economies".

How should this empirical relationship be interpreted? Stiglitz (2000) identifies three links between financial openness and volatility: the procyclical nature of capital flows; the sensitivity of international markets to changes in information; and the systemic risk through contagion from one economy to another. On the first link, there is considerable evidence that capital inflows are positively correlated with domestic business cycle conditions (see Reinhart (2002) and Kaminsky and Reinhart (2002)), i.e., flows are procyclical, supporting the popular cynicism that bankers only lend money to people who don't need it. On the second link, international financial liberalization increases the liquidity to which domestic borrowers have access and thereby amplify the effects of changes in international market sentiment. When market sentiment is high, capital market liberalization permits inflows of speculative capital which, in the East Asian case, were often associated with booms in real estate and construction. When market sentiment changes, inflows may be subject to "sudden stops" as bankers pull their money out of the economy (see Calvo and Reinhart, 1999). ${ }^{12}$ East Asia experienced a dramatic $\$ 109$ bn reversal in net capital flows (more than 10 per cent of GDP in the region) between 1996 and 1997. As capital flows out, banks are deprived of lending resources, forcing a credit contraction; exchange rates also fall, leading to increases in the value of dollar denominated debt.

Increased volatility induced by openness is almost certainly part of the reason why financial market liberalization does not appear to be correlated with growth in cross-

\footnotetext{
${ }^{11}$ Evidence on the effect of financial liberalization on the volatility of output is more mixed, but fluctuations in output are less important for poverty than consumption. Razin and Rose (1994) find that financial openness has no effect on the volatility of output in their sample of 138 countries. Similarly Easterly, Islam, and Stiglitz (2001) found neither the volatility of capital flows nor measures of financial openness had a significant impact on output volatility. O’Donnell (2001) finds that financial integration reduces output volatility in rich countries but increases it in poor countries.

${ }^{12}$ The causes of changes in market sentiment are difficult to identify ex ante. In Thailand the speculative inflows led to a real estate bubble, and when that bubble broke so did expectations of high returns. What seemed to be a change in market feeling about the risks of emerging markets hit Latin America in 1998.
} 
country studies, ${ }^{13}$ and it is also a smoking gun for investigations into the poverty effects of financial openness. Volatility has profound and persistent effects on the poor. Crises hurt both the poor and the rich, but the poor have the least resources and insurance mechanisms to respond. Empirical evidence shows that economic cycles have an asymmetric effect on poverty in the sense that contractions increase poverty more than similarly sized expansions (Morely 1994; Londono and Szekely 1997). In an analysis of inequality in Latin America between 1970 and 1994, De Janvry and Safoulet (1998) found that, on average, one year of recession had six times the (negative) impact on inequality that one year of growth was able to achieve. This may because the poorest and least-skilled workers also have the least secure employment, leading economic fluctuations to disproportionately harm the poor (Agenor 1998). Thus volatility may have an effect on poverty, independent of its effect on growth. In Mexico from 1984 to 1994 the poverty headcount rose from 28 to 34 per cent of the population, much of this increase ( 86 per cent) was due to the increase in inequality rather than falling GDP per capita (World Bank 2001). Hausmann and Gavin (1995) highlight the importance of macroeconomic volatility in explaining the weak economic performance of Latin America relative to East Asia. In particular, they find that a higher standard deviation of real GDP is associated with higher poverty, after controlling for other factors.

The asymmetric response of poverty to GDP levels is partly due to the effects of crises and recessions on the investment choices of the poor. Shocks may have long term effects on poverty through their impact on health, schooling, physical investment, and nutrition. For example, evidence from Indonesia suggest that the East Asian crisis led to a 5 per cent decline in secondary enrolment rates and a sharp drop in household expenditure on health services (Frankenberg, Thomas, and Beegle 1999). Through these mechanisms, negative shocks may have a chronic impact on poverty long after average incomes recover.

The affect of volatility on the poor has another dimension beyond income levels. Traditional poverty measures neglect several important dimensions of household welfare, perhaps most importantly the effects of risk on household welfare. Ligon and Schechter (2003) decompose the welfare of the poor into a contribution from poverty and a contribution from various sources of uncertainty. Using household data from Bulgaria, they find that risk plays a large role in reducing the welfare of the poor.

\subsection{Financial Crises, Poverty, and Liberalization}

In 1998 the number of people living in poverty in the four countries hardest hit by the Asian crisis increased by more than 60 per cent. In that year approximately 20 million people in those countries fell into poverty. ${ }^{14}$ Smaller but nonetheless significant

\footnotetext{
${ }^{13}$ One plausible explanation is that irreversibilities or asymmetric costs associated with investment increase uncertainty (see Pindyck, 1991). For further theoretical discussion of the relationship between growth and volatility in developing countries see Turnovsky and Chattopadhyay (1998). For an analysis of the effect of volatility on Africa see Guillaumont et al (1999) and for Latin America see Hausmann and Gavin (1995).

${ }^{14}$ World Bank (1998) estimates of the increase in poverty in Indonesia (17 million), Thailand (2.3 million), the Philippines $(665,000)$, and Malaysia $(500,000)$. The estimates use the US\$1 a day poverty
} 
increases in poverty were experienced in Latin America (World Bank 1998, Lustig 1999). If capital market liberalization significantly increases the risk of crises, these experiences provide a powerful rationale for maintaining controls in some form.

The link between capital account liberalization and the incidence of crises has not been uncontroversial. Crises have occurred in countries with both closed and open capital accounts, but, although it is too strong to claim a direct causal link, there is evidence (and good reasons) to believe that liberalization increases the incidence of crises. ${ }^{15}$ Eichengreen and Wyplosz (1993) argue that the relaxation of capital controls in Europe exposed governments to speculative pressures and culminated in the 1992 crisis. Furman and Stiglitz (1998) find that capital account liberalization in East Asia exacerbated moral hazard problems associated with government guarantees and led to structural instability in the banking system. By contrast, China's stunning resilience during the East Asian crisis may be partly explained by its controls on outflows of yuan and the absence of an onshore futures market, both of which limited the impact of speculation on the currency (Eichengreen 2001, Fernald and Babson 1999).

There are a small number of cross-country studies on this issue. They face the twin problems of nailing down a definition of currency crises and dealing with reverse causality. In particular, if crisis risk causes governments to change their capital account policies, it will difficult to identify a direction of causality in cross-country data. Using data for 90 countries over the period 1975-1997, Glick and Huchinson (2000) find that the presence of capital controls in one year is positively correlated with the occurrence of a crisis in the next. Their interpretation is that is that controls send a bad signal to the market, inciting investors to become suspicious of the government's macroeconomic policies. An alternative but related interpretation is that the results haven't identified the direction of causality. For example Malaysia's efforts to tighten controls during the crisis were a consequence of instability rather than a cause of it. Other cross-country studies have found evidence that financial liberalization increases the vulnerability of countries to crises. Kaminsky and Reinhart (1998) find that "in 18 out of 26 banking crises studied ... the financial sector had been liberalized during the preceding five years." In a panel of 53 countries Demirguc-Kunt and Detragiache (1998) find that banking crises are more likely to occur in liberalized financial systems. However, they also note that the effect of financial liberalization on the fragility of the banking sector is weaker when the institutional environment is strong. Case study evidence from several countries, beginning with the careful analysis of Chile's 1982 crisis by Diaz Alejandro (1985) presents more detailed analysis which has generally supported the role of financial liberalization in increasing exposure to risk of crises. ${ }^{16}$

Where does this evidence leave us in relation to the impact of financial market liberalization on poverty through the incidence of crises? It is perhaps not clear which of financial contagion (facilitated by international financial liberalization) or weak macroeconomic fundamentals should bear the primary blame for causing crises. Most of the detailed evidence suggests that exposure to large foreign capital flows plays an

line for Indonesia and the Philippines and US\$2 a day for Malaysia and Thailand. Total poverty in these countries almost doubled from approximately 30 million to 50 million.

${ }^{15}$ See Williamson and Mahar (1998) for a survey.

${ }^{16}$ For other national and regional studies see for example Steigum (1992) and Kiander and Vartia (1996) Furman and Stiglitz (1998). 
important role. But for the analysis of poverty there is perhaps a more important issue. Whatever the role played by financial market liberalization in causing crises, there is clear evidence that it exacerbates their effect on the poor. Financial openness increases the incidence of crises on the lives of the poor and simultaneously reduces the scope for government safety nets to protect them.

Independent of the issue of whether financial openness causes crises, there has been considerable debate about whether countries in crisis suffer more with open financial regimes. Certainly, the orthodox prescription for dealing with crises are particularly harsh for the poor. In response to the East Asian crisis Thailand, South Korea, and Indonesia embarked on IMF-supported programs to cope. They committed to floating their exchange rates, opening financial markets to foreigners, tightening fiscal policy (at least initially), lifting interest rates, closing insolvent banks, as well as other structural reforms. These policies had disproportionately adverse effects on the poor. High interest rates (proscribed to protect the currency) had a debilitating effect on net borrowers and many small businesses (in Thailand small businesses were going bankrupt at the rate of almost one thousand per month (Chomthongdi 2000)) leading to lower wages and increased unemployment. In addition falling exchange rates increased the price of imported food and other products, lifting costs for poor households that are net consumers of food.

Capital controls are an alternative to the standard prescription and have been used to limit short-term capital inflows by Brazil (1993-97), Chile (1991-98), Colombia (1993-98), and Thailand (1995-97). In 1998, Malaysia ultimately ignored the IMF's advice and took an alternative route. It imposed controls on capital outflows, ${ }^{17}$ pegged the exchange rate, reduced interest rates, and increased spending. Malaysia's capital controls were initially widely criticised and the ratings agency, Moody's, downgraded Malaysian securities to junk bond status. However despite predictions, Malaysia recovered from the Asian financial crisis swiftly after the imposition of capital controls in September 1998. The role played by capital controls in this recovery has been subsequently the subject of considerable debate. Opponents of controls point to the fact that Korea and Thailand recovered in parallel, suggesting that capital controls were not a key factor in Malaysia's rebound. Kaplan and Rodrik (2001) examine the timing of the crises and recovery across countries. They note that the financial crisis was deepening in Malaysia in the summer of 1998, while it had significantly eased up in Korea and Thailand. Their analysis concludes that compared to IMF programs, the Malaysian policies produced faster economic recovery, smaller declines in employment and real wages, and more rapid turnaround in the stock market.

The Malaysian experience demonstrated that the adoption of selective capital controls can be an effective means of limiting short-term speculative pressure. ${ }^{18}$ But the

\footnotetext{
${ }^{17}$ In Spetember 1998 foreigners were banned from removing portfolio capital for one year. In February 1999 , this was replaced by a tax on outflows.

18 Despite their warnings at the time, the IMF has since admitted the success of Malaysia's policies: "Since the introduction of the controls, there have been no signs of speculative pressures on the exchange rate, despite the marked relaxation of fiscal and monetary policies to support weak economic activity. Nor have there been signs that a parallel or nondeliverable forward market is emerging; and no significant circumvention of efforts have been reported." Ariyoshi et al (2000).
} 
Malaysian experiment was not without its risks and disadvantages,${ }^{19}$ nor will similar policies necessarily be effective in other countries facing different crisis challenges. However from the point of view of poverty, the controls were a success. They reduced the government's reliance on tight monetary policy and increased its scope to use fiscal policy to alleviate the problems of the poor. The next section discussed the fiscal implications of capital market liberalization in more detail.

\subsection{Capital mobility and bargaining power}

Financial openness might affect inequality and poverty by altering the relative bargaining power of labor and capital and thereby changing the labor share of GDP (Rodrik (1997) and Glyn (1995)). Rodrik (1997) argues that the increasing mobility of capital might be increasing its bargaining power over labor. ${ }^{20}$ Supporting this thesis, Slaughter (2001) documents a rise in the elasticity of labor demand in many countries, which seems to be correlated with, among other things, measures of openness.

In an imperfectly competitive theoretical framework, Harrison (2002) determines the division of excess profits between capital and labor as the outcome of bargaining process between them. In her model, bargaining strength is a function of the fixed costs of relocating and the alternative return available elsewhere. Applying the model to data for more than 100 countries over 40 years, Harrison finds that rising trade openness and exchange rate crises reduce labor's share of output, while capital controls and government spending increase labor's share. Jayadev (2004) estimates the effect of financial liberalization on the labor share of output using a constructed index of capital account restrictions for up to 140 countries over the period 19721996. This enables panel estimation of the effect of liberalization controlling for macroeconomic trends and changes in endowments. Jayadev finds that capital account openness exerts a robust and significant negative effect on the labor share of income. The effect is robust across subsets of developing and developed countries, contrary to the predictions of the Heckscher-Ohlin theory. Jayaev finds that labor's losses are not temporary, but persist through the medium term.

\subsection{Anti-poverty policies and market disciplines}

Capital account liberalization may constrain domestic policies to alleviate poverty. In particular, the government may lose some autonomy over fiscal policy and to the extent that this leads to a reduction in transfers, social programs, or public investment, the poor may be adversely affected. The openness constraint on fiscal policy is an application of Krugman's 'impossible trinity'; where a country cannot simultaneously maintain autonomous macro policy with an open capital account and a fixed

\footnotetext{
${ }^{19}$ Jomo (2001) points out that the controls were used in part as a mechanism to bail out the Malaysian administration's cronies.

${ }^{20}$ Similar arguments have been made by Freeman (1995), Slaughter (1998), and Budd and Slaughter, (2000)
} 
exchange rate. Increased exposure to short-term capital flows may affect the fiscal balance in several ways. The primary effect works through the government bond market: in particular the ability to maintain or increase the planned public sector borrowing requirement at reasonable rates of interest (FitzGerald 2001). Second, the budget balance will be affected by fluctuations in the costs of servicing external debt caused by changes in the exchange rate. Capital inflows causing appreciation improve the budget balance; capital outflows reduce it. As well as suffering a potential loss due to reduced government expenditure, Rodrik (1997) argues that the increasing mobility of capital may shift a greater share of the tax burden onto labor.

This implies that one way that capital market liberalization may lead to lower government expenditure is through a reduction in the scope for debt-financed deficits. There is some empirical evidence of the effect of openness on the size of government expenditure. Garrett and Mitchell (2001) find that international financial openness is negatively correlated with total government spending in 18 OECD countries. However, importantly for poverty, they did not find that capital mobility had deleterious effect on the welfare state: openness was not significantly related to social security transfers. Jayadev (2004) reports some evidence that capital account openness reduces budget deficits, but this was only true for developing countries. Garrett (1995) provides a potential explanation. He finds some evidence that countries with fewer capital controls have proportionately smaller government expenditure and smaller budget deficits, but determines that the relationship is conditional on the bargaining power of labor. This might explain the absence of a relationship between openness and reduced expenditure in OECD countries. Quinn (1997), in a sample of 64 countries finds no evidence that capital account liberalization reduces government expenditures. All these studies should be interpreted with caution since the effects of openness is difficult to separate from the effects of other reforms which may have been implemented at the same time. Case study evidence indicates that changes to capital account regimes are often introduced contemporaneously with other macroeconomic polices from which it is difficult to isolate the effects. In any case, even if financial openness results in only a small reduction in social spending, this may have a large effect on the poor, for whom transfers represent an important part of their incomes.

Externally imposed fiscal discipline may have long term effects on the poor if it leads developing countries to reduce their investment in infrastructure. Biggs (1998) finds that fiscal contractions in developing countries usually comprise larger reductions in investment spending than in social spending. FitzGerald (2001) argues that developing countries will find it easier politically easier to postpone promised investment programmes rather cut recurrent spending by, for example, laying off teachers and nurses. However the consequences of fluctuations in public investment may have large negative effects on the poor who rely on public services such as transport, education, health and development programs.

As well as experiencing a decline in social spending and public investment, financial openness may increase the share of the tax burden borne by labor. International financial liberalization may enable firms to shift taxable income between jurisdictions, leading to a reduction in tax revenue for many countries. As the elasticity of capital supply increases countries may respond by reducing the rate of capital taxation. However the evidence for a link between financial openness and 
corporate taxation rates is quite weak (see Garett (1995), Quinn(1997), Garrett and Mitchell (2000)). Eichengreen (2001) points out that part of the empirical confusion may be explained by the fact that most countries with open capital accounts are relatively high income, with large public sectors and large tax rates. Even if the effects of mobility are not observable in cross-country studies of taxation rates, there is nonetheless considerable evidence that increasing capital mobility causes governments to offer financial incentives and concessionary tax rates to international firms (Oman 2000).

Management of volatile capital flows through sterilized intervention in foreign exchange markets may impose additional constraints on government expenditure. In response to large capital inflows, governments often simultaneously sell domestic currency and government bonds. The first softens any exchange rate appreciation caused by capital inflows, while the second neutralizes its inflationary effect. These prudential management policies are associated with potentially significant costs if the government faces an interest rate premium on the foreign currency it borrows and holds as an asset. In addition, there is an opportunity cost of foregone expenditure. An increase in reserves is a government investment that could otherwise have been made in infrastructure, education, or health.

The disciplining effect of market forces on national policies is often advanced by proponents of capital market liberalization as a positive force, since countries that fail to pursue 'good' policies are quickly punished. As Stanley Fischer, former First Deputy Managing Director of the International Monetary Fund, said in 1997, capital markets serve as an important discipline on government macroeconomic policies "which improves overall economic performance by rewarding good policies and penalising bad." But underlying this belief is a fundamentally undemocratic ethic which would transfer authority from national democratic processes toward foreign financial interests. Market discipline may also be inefficient if capital market behaviour is subject to certain biases: for example fund managers may take a myopic view of government expenditures and fail to sufficiently differentiate between deficits which fund long term investments and those which fund consumption. In addition, international financial interests can be an erratic and arbitrary source of discipline. Eichengreen (2001) points out that international investors are prone to overlook domestic policy weaknesses until they are abruptly brought to their attention, at which point markets overreact. As Calvo and Mendoza (1996) suggest, the punishment may be greater than the crime if creditors' reactions cause a financial crisis.

\subsection{Access to credit}

Capital market liberalization facilitates the entry of foreign banks into the domestic market, as well as increasing the scope for domestic banks to engage in international transactions. Such reforms may alter the allocation of credit to different sectors in the economy and impact on poverty. Theory predicts that when allowed to freely compete, banks will become more efficient and support more profitable projects, leading to greater economy-wide efficiency (Fry 1988). There is considerable evidence to suggest that increasing financial depth leads to income growth (King and 
Levine 1993), and there is also evidence that improving access of the poor to financial services, particularly to credit and insurance against risk, strengthens the capacity of the poor to accumulate productive assets and maintain sustainable livelihoods (World Bank 2001). But this evidence coexists with doubts about whether capital market liberalization actually promotes financial depth for the poor as well as for the rich, i.e. whether it increases the distribution of credit or mainly increases access for the rich. Greenwood and Jovanovic (1990) argue that financial sector reform tends to exclude the poor from its benefits because they are unable to pay upfront set-up and access charges. Consequently financial liberalization leads to further inequality.

Information problems are also an important limitation on credit distribution. The cost of obtaining information about the profitability of potential projects is often a key determinant of lending decisions (Rothschild and Stiglitz, 1976). Stiglitz and Weiss (1981) show that where these information costs are high, credit may be withheld from potentially viable projects. While foreign banks may bring increased competition and efficiency to the domestic banking system of developing countries, information costs may cause them to shift the allocation of credit away from the poor.

The empirical evidence generally supports this conclusion. In a cross-country study, Klein and Olivei (1999) find that financial openness increases the ratio of liquid liabilities to GDP, suggesting that controls limit financial depth. However this result is limited to advanced industrial countries and breaks down when poor countries are considered, and, as we will see below, there is reason to believe that the relationship is even weaker when considering credit availability to the poor within developing countries. $^{21}$

The empirical evidence from more detailed country-level studies suggests that following capital market liberalization there is an expansion of credit to medium and large businesses, the foreign sector, and urban areas, but no effect (or even a contraction) to small enterprises and rural areas. ${ }^{22}$ Brownbridge and Gayi (1999) found evidence of credit expansion and financial innovation in the financial sector reform experiences of eight low income countries. In each country there was a growth in the number of foreign banks and increased competition precipitated several identifiable improvements in service. Some of the new entrants introduced longer banking hours, expanded credit and debit card services, increased the speed of check clearing and introduced automated teller machines. Financial depth - measured as the ratio of bank deposits and M2 to GDP - increased in three LDCs but declined in four after reform. The authors attribute the difference to the complementary effects of macroeconomic stability in the three countries experiencing financial deepening (all of which were in Asia) and the higher and more volatile inflation experiences of the other five countries (all of which were in Sub-Saharan Africa).

\footnotetext{
21 Levine and Zervos (1998) find that capital account openness leads to growth and increased liquidity in stock markets in developing countries. However stock market liquidity is not likely to directly benefit the poor in these countries.

22 These results have been confirmed in a number of analyses of the financial sectors reforms of developing and transition countries. Several studies find that levels of savings and investment have not increased (Gibson and Tsakolotos 1992) and access to bank credit has not improved (Nissanke 1990 and Kariuki 1995, for Africa; Mosley 1996, for eastern Europe; Cho and Khatkhate 1989, for Asia).
} 
Brownbridge and Gayi (1999) found that rural areas were likely to suffer a deterioration in the availability of financial services in the period following financial liberalization. The new foreign banks typically avoided rural areas and serviced mainly large and/or foreign corporate customers. The elimination of special lending and financing schemes and the closure of rural branches led to a reduction in credit to agriculture and small farmers. In particular, the share of agriculture in bank lending fell sharply in Malawi and Bangladesh in the wake of financial sector reforms.

Mosely (1999) analyses the availability of credit during the period of financial reform in four African countries: Uganda, Kenya, Malawi and Lesotho. The study concludes that credit availability to the poor increased only in Kenya and Uganda and that this was mainly accounted for by large increases in NGO lending in these countries. Where NGO lending did not increase, credit access to the poorest 10 per cent of the population actually declined over the period. Financial liberalization had similarly mixed consequences in Cambodia where liberalization proceeded rapidly after 1992. UNDP (2004) reports that reduced government intervention and increased competition among new commercial banks has brought benefits to the dollarized urban economy but has delivered little to the 90 per cent of the population living in

rural areas. Bank branches are concentrated in large population centers and 48 per cent of the population live in provinces with no bank branches at all.

\section{Conclusion}

The determination of the net effects of macroeconomic liberalization programs usually involves weighing the gains to average incomes against the costs to vulnerable groups who will be disadvantaged. The challenge for policymakers is to select a program of reform that appropriately balances risks and returns. For capital market liberalization in developing countries, the returns have been difficult to identify: there is no convincing empirical evidence linking open capital markets to economic growth. There is however, considerable evidence of increased risk. Capital market liberalization increases consumption volatility and heightens countries' vulnerability to crises.

Our analysis of five channels of causation suggests that the poor receive a small share of the gains from capital market liberalization and a large share of the risks. The poor are least equipped to cope with increased volatility, and they are most affected by financial crises. Capital mobility reduces their bargaining power relative to capital and leads to a decline in the labor share of output. Financial openness delivers the poor few benefits in terms of increased access to credit and other financial services, and it constrains governments' redistributive efforts and anti-poverty fiscal policies. While it is difficult to establish a conclusive direct link between capital market liberalization and increased rates of poverty, the evidence presented above suggests a compelling case that capital market liberalization is bad for the poor in developing countries. 
$\sim 16 \sim$ 


\section{References}

Agénor, Pierre-Richard. (1998). "Stabilization Policies, Poverty and the Labor Market: Analytical Issues and Empirical Evidence.” EDI, World Bank, Washington, D.C. December.

Ariyoshi, Akira, Karl Habermeier, Bernard Laurens, Inci Otker-Robe, Jorge Iván Canales-Kriljenko, and Andrei Kirilenko (2000) "Capital Controls: Country Experiences with Their Use and Liberalization" IMF Occasional Paper No 190, May 17, 2000.

Bekaert, G., Harvey, C.R., (2000). Capital flows and the behavior of emerging market equity returns. In: Edwards, S. (Ed.), Capital Flows and the Emerging Economies: Theory, Evidence and Controversies. NBER, pp. 159-194.

Biggs, M. (1998), 'Deficits and Economic Growth: Lessons from Developing Countries,' in I. Abedian \& M. Biggs (eds.), Economic Globalization and Fiscal Policy, Oxford: Oxford University Press.

Borensztein, Eduardo, and R. Gaston Gelos, (2002), “A Panic-Prone Pack? The Behavior of Emerging Market Funds," IMF Working Paper 00/198 (Washington: International Monetary Fund).

Borensztein, Eduardo, José De Gregorio, and Jong-Wha Lee, (1998), "How Does Foreign DIrect Investment Affect Growth?" Journal of International Economics, Vol. 45, pp. 115-35.

Brecher, Richard and Jagdish Bhagwati (1982), "Immiserizing Transfer from Abroad," Journal of International Economics 13, pp.353-364.

Brownbridge, Martin and Samuel Gayi (1999) "Progress, Constraints and Limitations of Financial Sector Reforms in The Least Developed Countries", Finance and Development Research Programme Working Paper Series, Paper No 7, IDPM, University of Manchester

Budd, John W., and Matthew J. Slaughter. (2000). "Are Profits Shared Across Borders? Evidence on International Rent Sharing." National Bureau of Economic Research Working Paper \#8014.

Calderón C. and A. Chong (2001), External sector and income inequality in interdependent economies using a dynamic panel data approach, Economics Letters $71,225-231$.

Calvo, Guillermo and Enrique Mendoza (1996), "Petty Crime and Cruel Punishment: Lessons from the Mexican Debacle," American Economic Review Papers and Proceedings 96, pp. 170- 175.

Calvo, Guillermo, and Carmen M. Reinhart, (1999), "Capital Flow Reversals, the Exchange Rate Debate, and Dollarization," Finance and Development, Vol. 36 (September), pp. 13-15.

Cho, Y-J. and Khatkhate, D. (1989), "Lessons of Financial Liberalization in Asia: a Comparative Study", World Bank Discussion Papers, No. 50. 
Choe, Hyuk, Bong-Chan Kho, and René Stulz, 1999, "Do Foreign Investors Destabilize Stock Markets? The Korean Experience in 1997," Journal of Financial Economics (Netherlands), Vol. 54, No. 2 (October), pp. 227-64.

Chomthongdi, J. (2000),'The IMF's Asian Legacy,' mimeo., Focus on the Global South.

Das, M. and Mohapatra, S., 2003, Income inequality: the aftermath of stock market liberalization in emerging markets, Journal of Empirical Finance 10, 217-248.

De Janvry, Alain, and Elisabeth Sadoulet. (1998(. Growth, Poverty and Inequality in Latin America: a Causal Analysis, 1970-94. Univeristy of California at Berkeley. September. (Presented at the Inter-American Development Bank Conference on Social Protection and Poverty. February 1999.)

De Mello, Luiz, (1999), "Foreign Direct Investment-Led Growth: Evidence from Time Series and Panel Date," Oxford Economic Papers, Vol. 51, No. 1 (January), pp. $133-51$.

Demirguc-Kunt, Asli and Enrica Detragiache (1998) "Financial liberalization and Financial fragility" Working Paper WP/98/83. International Monetary Fund. Washington D.C.

Devenow, A. and I. Welch (1996) "Rational herding in financial economics", European Economic Review, 40, 603-615.

Diaz-Alejandro, Carlos F. (1985) "Good-bye financial repression, hello financial crash," Journal of Development Economics 19,

Dollar, D., Kraay, A., (2001). "Growth is good for the poor", World Bank Policy Research Working Paper, 2587.

Easterly, William, R. Islam, and Joseph E. Stiglitz, (2001), "Shaken and Stirred: Explaining Growth Volatility," in B. Pleskovic and N. Stern. (eds) Annual World Bank Conference Volume on Development Economics, 2001.

Eichengreen, B., and Wyplosz, C., (1993) “The Unstable EMS”, Brookings Papers on Economic Activity, 1, The Brookings Institution, Washington DC, 1993.

Eichengreen, Barry (2001), Capital Account Liberalization: What Do the CrossCountry Studies Tell Us? The World Bank Economic Review. Vol 15, No. 3, 341-365.

Fernald, John G. and Oliver D. Babson, (1999) 'Why has China survived the Asian crisis so well? What risks remain?', Board of Governors of the Federal Reserve System, International Finance Discussion Papers, Number 633, February.

Fischer, S., (1997), "'Capital Account Liberalization and the Role of the IMF," Paper presented at the seminar Asia and the IMF, held in Hong Kong, China, on September 19, 1997. IMF, September 1997

FitzGerald, Edmund. V. K. (2001) "Short-Term Capital Flows, The Real Economy And Income Distribution In Developing Countries" QEH Working Paper Series, No. 8, QEHWPS08

Frankenberg, Elizabeth, Duncan Thomas, and Kathleen Beegle. (1999). "The Real Costs of Indonesia's Economic Crisis: Preliminary Findings from the Indonesia Family Life Surveys." Labor and Population Program Working Paper Series 99-04, Rand, Santa Monica, Calif. March. 
Freeman, Richard B., (1995), “Are Your Wages Set in Beijing?” Journal of Economic Perspectives Vol 9, No. 3, 15-32.

Frenkel, Jacob A. and Assaf Razin (1996), Fiscal Policies and Growth in the World Economy, Cambridge, Mass.: MIT Press (3rd edition).

Fry, Maxwell (1988), Money, Interest and Banking in Economic Development, Baltimore, John Hopkins UP.

Furman, Jason \& Joseph E. Stiglitz, (1998). "Economic consequences of income inequality," Proceedings, (Aug) pp. 221-263. Federal Reserve Bank of Kansas City

Garrett, Geoffrey, and Deborah Mitchell. 2001. "Globalization, Government Spending, and Taxation in the OECD." European Journal of Political Research 39:145-177.

Garrett, Geoffrey. (1995). "Capital Mobility, Trade, and the Domestic Politics of Economic Policy."International Organization 49(4):657-87.

Gibson, H. and E. Tsokolotos, (1994), 'The scope and limits of financial liberalization in developing countries: a critical survey', Journal of Development Studies, vol 30, 562-578.

Glick, Reuven and Michael Hutchinson (2000), "Stopping 'Hot Money' or Signaling Bad Policy? Capital Controls and the Onset of Currency Crises," unpublished manuscript, Federal Reserve Bank of San Francisco and UC Santa Cruz.

Glyn, Andrew. (1995). "Social Democracy and Full Employment", New Left Review, 211, pp. 33-55.

Greenwald, Bruce, and Stiglitz, Joseph E., (1986) "Externalities in Economies with Imperfect Information and Incomplete Markets," Quarterly Journal of Economics, May, pp. 229-264.

Greenwood, Jeremy and Boyan Jovanovic (1990) "Financial Development, Growth, and the Distribution of Income", The Journal of Political Economy, Vol 98, No. 5, 1990, 1076-1107.

Guillaumont, Patrick, Sylviane Guillaumont Jeanneney, and Jean-François Brun. (1999). "How Instability Lowers African Growth." Journal of African Economies 8 (1): 87-107.

Harrison, Ann. (2002). "Has Globalization Eroded Labor's Share? Some CrossCountryEvidence", mimeo, University of California, Berkeley.

Hausmann, Ricardo, and Michael Gavin. (1995). "Overcoming Volatility in Latin America." International Monetary Fund Seminar Series (International); No [199534]:1-86. August.

Henry, P.B., (2000). Stock market liberalization, economic reform, and emerging market equity prices. Journal of Finance 55, 529- 564.

Howes, C., \& Singh, A. (1995). Long-term trends in the world economy: the gender dimension. World Development, 23 (11), 1895 1911.

Ishac Diwan, (2001). "Debt As Sweat: Labor Financial Crisis and The Globalization of Capital", mimeo, World Bank.

Jayadev, Arjun, (2004) "The impact of capital account liberalization on the labor share of income" mimeo, University of Massachusetts. 
Jomo, K.S., (2001) "Capital Controls," in Jomo, ed., Malaysian Eclipse: Economic Crisis and Recovery, Zed Books, London and New York, 2001.

Kaminsky, G. \& Reinhart, C. (1998), 'The Twin Crises: The Causes of Banking and Balance of Payments Problems', Board of Governors, Federal Reserve System, mimeo.

Kaminsky, Graciela, and Carmen M. Reinhart (2002), "The Center and Periphery: The Globalization of Financial Turmoil," NBER Working Paper W9479.

Kaminsky, Graciela, Richard Lyons, and Sergio Schmukler, 1999, "Managers, Investors, and Crisis: Mutual Fund Strategies in Emerging Markets," World Bank Working Paper 2399 (Washington: World Bank).

Kaplan, Ethan and Dani Rodrik (2001) "Did The Malaysian Capital Controls Work?" mimeo, John F. Kennedy School of Government, Harvard University.

Kariuki, Peninah W.(1995) 'The effects of liberalization on access to bank credit in Kenya', Small Enterprise Development, vol 6 no 1(March), 15-23.

Kiander, J. and Vartia, P. (1996), The Great Depression of the 1990s in Finland, Finnish Economic Papers9, 72-88.

Kim, Woochan, and Shang-Jin Wei, 2002, "Foreign Portfolio Investors Before and During a Crises," Journal of International Economics, Vol. 56, pp. 77-96.

King, Robert G. and Ross Levine: "Finance, Entrepreneurship, and Growth: Theory and Evidence", Journal of Monetary Economics 32, 1993, 513-542.

Klein, Michael and Giovanni Olivei (1999), "Capital Account Liberalization, Financial Depth and Economic Growth,” NBER working paper, 7384, Cambridge Mass.

Kose, M. Ayhan, Eswar S. Prasad, and Marco E. Terrones, (2003), "Financial Integration and Macroeconomic Volatility," Staff Papers, International Monetary Fund.

Krugman, Paul (1996), “Are Currency Crises Self-Fulfilling?” NBER Macroeconomics Annual, pp.345-377.

Levine, Ross and Sara Zervos (1998), "Capital control liberalization and stock market development," World Development, 26 (7), 1169-83.

Ligon, Ethan and Laura Schechter (2003) "Measuring Vulnerability" The Economic Journal, Volume 113, Issue 486.

Londoño, Juan Luis, and Miguel Székely. (1997). "Distributional Surprises After a Decade of Reforms: Latin America in the Nineties." Working Paper 352. Office of the Chief Economist. Inter-American Development Bank, Washington, D.C. August.

Lustig, Nora (1999) "Crises and the Poor: Socially Responsible Macroeconomics" mimeo, Inter-American Development Bank, Washington D.C.

McKinnon, Ronald and Huw Pill (1997), "Credible Economic Liberalizations and Overborrowing," American Economic Review Papers and Proceedings 87, pp.189193.

Morley, Samuel. (1994). Poverty and Inequality in Latin America: Past Evidence, Future Prospects. Overseas Development Committee, Washington, D.C. 
Mosley, P (1996) 'Financial reform in transitional economies: a preliminary assessment of impact', paper presented to conference on Economic Reform in the Post Soviet World, November.

Mosley, Paul (1999) "Micro-Macro Linkages in Financial Markets: The impact of financial liberalization on access to rural credit in four African countries" Finance and Development Research Programme Working Paper Series, Paper No. 4, Institute for Development Policy and Management (IDPM), Manchester, March 1999.

Nathan, D., \& Kelkar, G. (1999). "Agrarian involution domestic economy and women. Rural dimensions of the Asian crisis". Economic and Political Weekly, 11351141.

O’Donnell, Barry, 2001, "Financial Openness and Economic Performance" mimeo, Trinity College Dublin.

Oman, Charles, (2000) Policy Competition for Foreign Direct Investment : A study of Competition among Governments to Attract FDI, OECD Development Centre Studies.

Ozler, S. (1999). "Globalization, employment and gender". Background paper prepared for the UNDP Human Development Report.

Pindyck, Robert S. (1991). "Irreversibility, Uncertainty and Investment." Journal of Economic Literature 29 (3): 1110-48. September.

Prasad, Eswar Kenneth Rogoff, Shang-Jin Wei and M. Ayhan Kose (2003): 'Effects of Financial Globalization on Developing Countries: Some Empirical Evidence". International Monetary Fund

Quinn, Dennis P. (1997a), "The Correlates of Changes in International Financial Regulation," American Political Science Review 91, pp. 531-551.

Rakshit, M. K.(2001), "Globalisation of capital markets: Some analytical and policy issues", in Globalisation and Economic Development, Essays in honour of Waardenburg, Eds. Storm, Naastepad. Edward Elgar, UK. MA. USA

Razin, Assaf, and Andrew K. Rose, (1994), "Business-Cycle Volatility and Openness: An Exploratory Cross-Sectional Analysis," in Capital Mobility: The Impact on Consumption, Investment, and Growth, ed. by Leonardo Leiderman and Assaf Razin, pp. 48-76 (Cambridge: University Press).

Reinhart, Carmen M. (2002), "Credit Ratings, Default and Financial Crises: Evidence from Emerging Markets," World Bank Economic Review. Vol. 16 No. 2, 2002, 151170.

Rodrik, Dani (1997) Has Globalization Gone Too Far? Institute for International Economics, Washington, D.C.

Rodrik, Dani. (1998) “Who needs capital account convertibility?" Princeton Essays in International Finance 207, pp. 55-65.

Rothschild,M. and J.Stiglitz(1976) 'Equilibrium in competitive insurance markets: an essay in the economics of imperfect information', Quarterly Journal of Economics,vol.86, pp.629-649.

Singh, A., and A. Zammit, (2000), " International Capital Flows: Identifying the Gender Dimension." World Development. 28 (7):1249-1268. 
Singh, Ajit (2002) "Capital account liberalization, free long-term capital flows, financial crises and economic development" ESRC Centre for Business Research Working Papers, No. 245.

Slaughter, M. (1999) Globalisation and Wages, The World Economy, Vol. 22, pp.609630.

Slaughter, Matthew, (2001) "International Trade and Labor-Demand Elasticities", Journal of International Economics, 54(1), 27-56, June,.

Steigum, E. (1992): Financial deregulation, credit boom and banking crisis: the case of Norway. Norwegian School of Economics and Business Administration, Discussion Paper 15/92.

Stiglitz J. and A. Weiss (1981), 'Credit rationing in markets with imperfect information', American Economic Review, vol.71, pp.393-410.

Stiglitz, Joseph E. (2000),"Capital Market Liberalization, Economic Growth, and Instability." World Development, 28 (6): 1075

Stiglitz, (1994) "The Role of the State in Financial Markets", in Proceedings of the World Bank Annual Conference on Development Economics 1993, pp19-52.

Summers, L., (2000). " International Financial Crises: Causes, Prevention and Cures." American Economics Review papers and Proceedings. 90 (2): 1-16.

Turnovsky, Stephen and Pradip Chattopadhyay (1998) "Volatility and Growth in Developing Economies: Some Numerical Results and Empirical Evidence"

Discussion Paper in Economics, Department of Economics at the University of Washington.

UNDP (2004) "The macroeconomics of poverty reduction in Cambodia" Asia-Pacific Regional Programme on The Macroeconomics of Poverty Reduction.

Wei S. J. and Y. Wu (2002): “Life and Death Implications of Globalization,” IMF Working Paper.

Williamson, J and Mahar, M (1998) ‘A Survey of Financial Liberalization' Princeton Essays in International Finance No. 211, November

World Bank (2001) World Development Report, Oxford University Press, New York.

World Bank, (1998). Global Economic Prospects. New York: Oxford University Press. 